\title{
KS. PROF. DR HAB. AUGUSTYN ECKMANN - CURRICULUM VITAE EIUS ET LAUDATIO
}

Wyróżnieniem wielkim jest przedstawienie osoby bardzo zasłużonego pracownika naszej Alma Mater - uczonego, pedagoga, kapłana. I choć czynię to na Jego prośbę, odczuwam pewien wewnętrzny opór. I nie jest to topos skromności. Trudność leży w tym, że w przedstawianiu osoby ks. prof. Augustyna Eckmanna na Katolickim Uniwersytecie Lubelskim Jana Pawła II kryje się jakby sprzeczność, rodzaj niestosowności. Wrósł on przecież w krajobraz uczelni, w jej sale, audytoria i gabinety. Wszyscy Go znają. Jeśli zatem mamy Go przedstawiać, to tylko po to, aby uporządkować to, co o Nim wiemy lub powinniśmy wiedzieć, i tylko po to, abyśmy winszując Mu osiągnięć, starali się brać wzór z nich i z zalet Jego ducha.

Augustyn Eckmann urodził się 25 maja 1941 r. w Ostrowitem w powiecie chojnickim, w obecnym województwie pomorskim, diecezji chełmińskiej. Lata Jego dzieciństwa to noc okupacji. Tam, na wąskim przesmyku Polski między niemieckim Pomorzem a Prusami Wschodnimi, ta noc była ciemniejsza niż tu, w Polsce centralnej, w Lublinie. Potworność tamtego czasu, biedę i grozę wojny łagodziła miłość i opieka rodziców, dobroć braci i sióstr. Tam się zaczęła droga, która miała Go doprowadzić do naukowych osiągnięć.

1. Vir trilinguis. Kulturą klasyczną Augustyn Eckmann zaczął się interesować bardzo wcześnie, już na lekcjach języka łacińskiego w szkole średniej, w Leoninum w Wejherowie, a potem w Marianum w Pelplinie. Te zainteresowania rozwinęły się w czasie studiów w Seminarium Duchownym, a zrealizowały już po święceniach podczas studiów na Sekcji Filologii Klasycznej Wydziału Nauk Humanistycznych KUL. Ks. Augustyn był równocześnie studentem Szkoły Biblijnej Wydziału Teologicznego. Poznawał antyczną kulturę żydowską, grecko-rzymską i chrześcijańską oraz trzy ważne dla humanisty języki: hebrajski, grecki i łaciński. Najpierw uzyskał tytuł magistra nauk biblijnych i licencjata teologii, a następnie - magistra filologii klasycznej (1976). Stopień doktora teologii w zakresie nauk biblijnych (1978) i stopień doktora habilitowanego nauk teologicznych w zakresie starochrześcijańskiej literatury (1987) uzyskał na Wydziale Teologicznym. Zaangażowany w 1992 r. na stanowisku profesora nadzwyczajnego, dwa lata później został kierownikiem nowo utworzonej Katedry Literatury Wczesnochrześcijańskiej na Sekcji Filologii Klasycznej. Tytuł naukowy profesora nauk humanistycznych uzyskał w $1999 \mathrm{r}$. 
Do doktoratu badania naukowe ks. Eckmanna koncentrowały się głównie na pracy filologicznej prowadzonej nad tekstem biblijnym hebrajskim i greckim. Potem skupiły się na pisarzach wczesnochrześcijańskich, a w szczególności na św. Augustynie, czego wynikiem była rozprawa habilitacyjna Dialog świętego Augustyna ze światem pogańskim w świetle jego korespondencji (1987). Po habilitacji badania obejmują trzy zasadnicze kierunki: literaturę wczesnochrześcijańską, Biblię i historię kultury. Z jednej strony usiłuje przybliżyć stosunek pisarzy wczesnochrześcijańskich do kultury klasycznej, z drugiej - wykazać ich wkład w chrześcijańską kulturę Europy. W dużej mierze pozostaje jednak przy twórczości św. Augustyna.

O osiągnięciach naukowych mówią liczby: ponad 90 referatów na krajowych i zagranicznych kongresach, sympozjach i sesjach, ok. 100 artykułów, studiów bądź monografii, książki Symbol Apostolski w pismach świętego Augustyna (1999) i Przebóstwienie człowieka w pismach wczesnochrześcijańskich (2003), przekład Caeremoniale Episcoporum, ponad 40 haseł encyklopedycznych oraz ok. 100 prac przeglądowych i popularnonaukowych. Ksiądz Profesor zajmuje godnie miejsce po wybitnych uczonych, pod których kierunkiem się kształcił w Instytucie Filologii Klasycznej, ale także w gronie badaczy chrześcijańskiego antyku.

2. Pedagog - prodziekan - społecznik. W parze z pracą naukową Księdza Profesora idzie praca pedagogiczna, organizacyjno-naukowa i społeczna. Miejscem pierwszoplanowych zajęć dydaktycznych jest Instytut Filologii Klasycznej, ale uczył także $w$ innych instytutach: Kulturoznawstwa na Wydziale Filozofii KUL, Wyższej Kultury Religijnej przy KUL, w Wyższym Seminarium Duchownym w Pelplinie i w punkcie konsultacyjnym ówczesnej Akademii Teologii Katolickiej w Tczewie. Jest współautorem przekładu Statutu KUL na język łaciński. Wypromował 9 doktorów, 115 magistrów, 20 licencjuszy, recenzował 12 rozpraw habilitacyjnych, 20 doktorskich i ponad 220 magisterskich; do tego należy doliczyć recenzje dla centralnej komisji do spraw tytułu i stopni naukowych, do tytułu profesora, na stanowisko profesora zwyczajnego i nadzwyczajnego oraz wydawnicze. Niezrealizowanym, jak dotąd, pragnieniem Księdza Profesora, wnioskiem ciągle przezeń postulowanym, jest obecność na studiach w Instytucie Latinitatis vivae - żywej, mówionej łaciny.

Jubilat pełnił ważne funkcje uniwersyteckie: Prodziekana Wydziału Nauk Humanistycznych do Spraw Nauki i Kontaktów z Zagranicą (1999-2002) i Prodziekana do Spraw Studenckich przez dwie kadencje (2002-2008), obowiązki Dyrektora Instytutu Filologii Klasycznej (2011-2012).

Olbrzymi jest wkład Jubilata w uregulowanie spraw tytułu naukowego i stopni naukowych na uczelniach kościelnych w odrodzonej Polsce. Jako konsultor Rady Naukowej Konferencji Episkopatu Polski i sekretarz tejże Rady doprowadził do skutku zaległe sprawy zatwierdzenia habilitacji i przedstawienia doktorów habilitowanych do tytułu naukowego profesora na Papieskiej 
Akademii Teologicznej i na papieskich wydziałach teologicznych (w sumie sto kilkanaście spraw). Wieloraka jest również działalność, jaką Ksiądz Profesor wykonywał i wykonuje społecznie. Wymienię niektóre tylko byłe lub obecne funkcje: sekretarz Senatu Akademickiego, członek wielu komisji senackich, członek Komitetu Redakcyjnego zeszytu 3 „Roczników Humanistycznych KUL" (filologia klasyczna), sekretarz Sekcji Filologicznej przy Komisji Episkopatu do Spraw Nauki Katolickiej, funkcje w Oddziale Lubelskim PTF, w Komisji Badań nad Antykiem Chrześcijańskim, w Radzie Naukowej „Vox Patrum", wreszcie prezes Towarzystwa Naukowego KUL. Gdy te funkcje wyliczamy, mamy świadomość, ile czasu Ksiądz Profesor na to wszystko poświęcił oraz ile trudu w sprawy z tym związane włożył i nadal wkłada.

3. Kapłan. W końcu trzeci obszar działalności - trzeci, choć pierwszy w chronologii życia i pewnie pierwszy w ostatecznej hierarchii rzeczy. To kapłaństwo. Nie jest ono dla Księdza Profesora jedynie przedmiotem naukowych studiów.

Owszem, analizując utwory starożytne, pisząc o teologii kapłaństwa i tożsamości kapłana, sam jest przykładem kapłana uczonego i pobożnego. W tych dwóch określeniach nie ma antynomii. Uczony i pobożny - takimi byli wielcy Kościoła starożytnego.

Powołanie kapłańskie Augustyna Eckmanna narodziło się i zaczęło dojrzewać gdzieś w średnich kolegiach kościelnych, a umocniło się w Wyższym Seminarium Duchownym w Pelplinie (1959-1965). Diakon Augustyn przyjął święcenia kapłańskie z rąk biskupa Kazimierza Kowalskiego w 1965 r. W kościele w Borzyszkowach jako neoprezbiter odprawił mszę prymicyjną, podczas której wypowiedział u stopni ołtarza słowa ministrantury rozpoczynające każdą Mszę: „Introibo ad altare Dei. Ad Deum qui laetificat iuventutem meam". Nie wiedział pewno, że język Kościoła rzymskiego miał w niedalekiej przyszłości być narzędziem Jego naukowych badań, otworzyć przed Nim twórczość pisarza, którego imię nosi. Po święceniach było jednak sześć lat pracy w duszpasterstwie. Potem studia i praca naukowa, one jednak nie przeszkodziły Mu w posłudze kapłańskiej. Była nią opieka duszpasterska nad studentkami świeckimi oraz siostrami, jest nią nieprzerwanie od ponad 16 lat wymagająca gorliwości i wewnętrznej dyscypliny funkcja ojca duchownego w Konwikcie Księży Studentów - głoszenie homilii, cotygodniowych konferencji, prawie codzienny udział w nabożeństwach. Władza diecezji chełmińskiej, obecnie pelplińskiej, doceniając zasługi Księdza Profesora, odznaczyła Go godnością Kanonika Honorowego Kapituły Pelplińskiej, a papież - godnością Prałata Jego Świątobliwości. Mówiąc o posłudze kapłańskiej, trudno wyliczyć, ile różnorakiego dobra ludzie doświadczyli dzięki Niemu; na Uniwersytecie są tacy, którzy mówią o Nim „Kochany Ksiądz Profesor”. 
Na jubileusz 70. urodzin można przytoczyć słowa poety: „Tempore vita brevis, meritis fit longior almis / Angustosque dies tendit honore fides"' ${ }^{\text {. W tym }}$ dwuwierszu Wenancjusz Fortunat zamknął egzystencjalną prawdę - tym, co wydłuża nasze krótkie życie, są zasługi, a nasze dni, gdy stają się jakby przyciasne, czyni pięknymi wiara. Tendere to m.in. natężać, napinać uwagę, umysł, ducha; tendere - to także nastroić na przykład barbiton, instrument podobny do liry. Dies tendere ... to natężać ducha, napinać uwagę, życie stroić jak lirę.

Prześwietnemu Księdzu Profesorowi życzymy zdrowia i długich lat pełnych dalszych naukowych osiągnięć, lat obfitujących w życzliwość ludzką i w zasługi u Boga.

Na zakończenie warto przytoczyć słowa, których pewnego dnia 426 r., słuchał św. Augustyn. Lud zebrany w bazylice w Hippo Regius wołał, a notariusze skrzętnie notowali, a nawet policzyli jego radosne okrzyki, abyśmy i my mogli je powtórzyć: „Deo gratias! [...] Augustino vita! [...] Bene meritus! Bene dignus! [...] Dignus et iustus est!"’2.

Instytut Filologii Klasycznej KUL dla uhonorowania 70. urodzin Księdza Profesora Augustyna Eckmanna zadedykował $\mathrm{Mu}$ konferencję naukową: Christo parata via est. Prekursorzy i twórcy kultury europejskiej, która odbyła się w Lublinie na Katolickim Uniwersytecie Lubelskim Jana Pawła II, w dniach 21-22 marca 2013 r. Jej tematyka - Prekursorzy i twórcy kultury europejskiej - harmonizowała z zainteresowaniami badawczymi Księdza Profesora, była jednak na tyle szeroka, że mogli w niej odnaleźć się przedstawiciele różnych dyscyplin, nie tylko filologii klasycznej. Motto - Christo parata via est - to słowa z Contra Symmachum Prudencjusza, poety z IV w.: ,, ... [ Christo iam tunc venienti / crede, parata via est"3. Tematyka konferencji korespondowała z wizją Europy papieża Benedykta XVI. Jest nią Christianitas wsparta na fundamentach greckich, rzymskich i chrześcijańskich - zapora dla liberalizmu, agnostycyzmu i nihilizmu. Zaiste, jak pisał przeszło pół wieku temu Thomas Eliot: ,[...] wybór, jaki się rysuje przed nami, to albo stworzenie nowej kultury chrześcijańskiej, albo zgoda na kulturę pogańską"4.

ks. Tadeusz Gacia - Lublin, KUL

\footnotetext{
${ }^{1}$ Venantius Fortunatus, Carmen I 8, 1-2, PL 88, 70 B.

${ }^{2}$ Augustinus, Epistula 213, ed. A. Goldbracher, CSEL 57, Vindobonae - Lipsiae 1911, 375-376.

${ }^{3}$ Prudentius, Contra Symmachum II 620-621, ed. M.P. Cunningham, CCL 126, Turnhout 1966, 232.

${ }^{4}$ T. Eliot, Chrześcijaństwo. Kultura. Polityka, thum. P. Kimla, Warszawa 2007, 31.
} 